Review

\title{
Brewer's Spent Yeast (BSY), an Underutilized Brewing By-Product
}

\author{
Alice Jaeger ${ }^{1}$, Elke K. Arendt ${ }^{1,2}$, Emanuele Zannini ${ }^{1}$ (I) and Aylin W. Sahin ${ }^{1, *(1)}$ \\ 1 School of Food and Nutritional Science, University College Cork, T12K8AF Cork, Ireland; \\ 116458826@umail.ucc.ie (A.J.); e.arendt@ucc.ie (E.K.A.); e.zannini@ucc.ie (E.Z.) \\ 2 APC Microbiome Institute, University College Cork, T12YT20 Cork, Ireland \\ * Correspondence: aylin.sahin@ucc.ie; Tel.: +353-021-490-2388
}

Received: 26 November 2020; Accepted: 9 December 2020; Published: 11 December 2020

\begin{abstract}
The repurposing of by-products and the reduction of waste from food processing streams is an ever-increasing area of interest. Brewer's spent yeast (BSY) is a prevalent by-product of the brewing industry. The spent yeast cells are removed at the end of the bulk fermentation. A small amount of it is used to start the next batch of fermentation; however, the majority of the spent yeast is discarded. This discarded yeast is high in nutrients, in particular proteins, vitamins and minerals, as well as containing functional and biologically active compounds such as polyphenols, antioxidants, $\beta$-glucans and mannoproteins. At present, BSY is mainly used in animal feed as a cheap and readily available source of protein. This review explores alternative, value-added applications for brewer's spent yeast including nutritional ingredients, functional food additives as well as non-food applications. A major challenge in the utilization of BSY in food for human consumption is the high level of RNA. An excess of RNA in the diet can lead to an increase in uric acid in the bloodstream, potentially causing painful health conditions like gout. This issue can be overcome by RNA degradation and removal via additional treatment, namely heat treatment and enzymatic treatment. There is potential for the use of BSY ingredients in various food applications, including meat substitutes, bakery products and savory snacks.
\end{abstract}

Keywords: fermentation; brewer's yeast; saccharomyces cerevisiae; yeast $\beta$-glucans; food applications

\section{Introduction}

Yeast is a single-celled organism used in beer manufacture for the transformation of sugars from grain to alcohol. Brewer's spent yeast (also known as residual yeast or surplus yeast) is a prevalent by-product of the brewing industry, created when the yeast used in fermentations is no longer useful and must be disposed of. It is estimated that 15 to 18 tons of surplus yeast are produced per $10,000 \mathrm{hL}$ of finished beer [1]. Other major by-products include brewer's spent grains and hot trub. Brewer's spent yeast (BSY) is a rich source of B vitamins, proteins (45-60\%) and other compounds that could be applicable to both food and non-food products [2]. However, the high level of nucleic acids in BSY limits its use as a protein supplement in humans due to the negative health effects caused by an excess of uric acid [2,3]. Therefore, to date, BSY is mainly utilized in animal feed formulations as a low-cost source of protein.

Yeast extracts formed by the breakdown of the yeast cell membrane can be used as additives in food products as a source of free amino acids, peptides or for their antioxidant properties [2]. Compounds such as $\beta$-glucans and mannoproteins can also be derived from BSY. These have many functional uses in food products such as textural stabilization, as well as potential health benefits [4]. Due to these properties, there is a huge range of possible applications for BSY as a functional food additive. 
During the production of beer, yeast ferments the simple sugars present in the cooled wort to alcohol. In brewing, yeasts are generally classified into two broad categories: Top-fermenting 'ale' yeasts which consists of Saccharomyces cerevisiae strains and bottom-fermenting 'lager' yeasts of Saccharomyces pastorianus and Saccharomyces carlsbergensis strains [5]. The yeast strain used can have a significant impact on the overall quality of the beer. Along with ethanol and carbon dioxide, the yeast produces other compounds that can play a key role in the sensory properties of the beer, including a wide variety of esters, ketones, aldehydes and higher alcohols [6]. Generally, Saccharomyces species are used in brewing, however, in recent years there has been increasing interest in the use of non-Saccharomyces species in the production of low-alcohol or alcohol-free beers [7]. Yeast is separated from the bulk at the end of fermentation by a process known as flocculation which occurs towards the end of the fermentation process. During this process, thousands of yeast cells form 'flocs' which then either rise to the surface (top-fermenting) or sediment on the bottom of the vessel (bottom fermenting) [8]. Good flocculation properties are essential in an industrial strain as yeast can be reused multiple times during the brewing process [9]. A small amount of yeast from the previous fermentation is used to start the next fermentation in a process known as re-pitching. Due to only a small percentage being re-used in the manufacturing process, there remains a large excess of spent yeast. Due to BSY having a high chemical oxygen demand (COD) value of $0.53 \mathrm{~kg} / \mathrm{hL}$, it cannot be disposed of into wastewater streams without prior treatment as it would have a severe negative effect on the environment [1].

Essentially, brewer's spent yeast is an underutilized by-product of the brewing industry that has many potential uses. Food and beverage manufacturers are increasingly interested in waste reduction and reducing their environmental impact and so, due to its low cost and high nutrient density, brewer's spent yeast is a very valuable raw material. BSY could be utilized by a wide variety of industries in the production of nutritional supplements, functional food ingredients and other value-added products.

\section{Use of Yeast in Brewing and Fermentation-An Overview}

In order to understand the value of BSY and its potential applications, it is important to comprehend how spent yeast is formed, the role yeast plays in the brewing process and the processes involved in creating the by-product.

\subsection{Yeast}

Yeast is a eukaryotic, single-celled organism classified as a member of the Fungi kingdom [1]. There are thousands of naturally occurring wild yeast strains. Brewing originated by harnessing these wild strains in conjunction with other microorganisms to produce a fermented beer product. Nowadays, the strains used for brewing are much more strictly controlled, widely studied, and carefully maintained. Yeast cells are approximately $10 \mu \mathrm{m}$ in diameter and are complex organisms, consisting of several organelles, each with a defined purpose. Saccharomyces cerevisiae, the main strain used in brewing, contains 16 chromosomes within the nucleus of the cell [10]. Yeasts can be haploid, diploid or aneuploid, meaning they contain one, two, or three copies of each gene, respectively. Brewer's yeasts are aneuploid, therefore making them more stable, less prone to mutations and consistent over several generations which is beneficial in brewing to produce a consistent product [10]. The yeast cell is surrounded by a cell wall and a cell membrane which gives structure to the cell but also plays a key role in certain processes, namely flocculation. Disruption of this membrane is a key step in processing of BSY to produce yeast extract. Yeast can grow aerobically or anaerobically but only the anaerobic 'fermentative' mode of growth is applicable in brewing. During fermentation, yeast cells grow and multiply producing valuable by-products, namely alcohol, carbon dioxide and flavor compounds [11].

\subsection{A Brief Overview of Fermentation}

Fermentation is the process by which sugars in the wort are transformed into alcohol, carbon dioxide and other by-products by the yeast cells. The first stage of fermentation is known as the 
'primary fermentation'. During this process, the yeast cells use nutrients supplied by the wort to grow and multiply. The by-products of this process are alcohol, carbon dioxide and numerous flavor compounds. Yeast metabolizes sugar according to the following:

$$
\mathrm{C}_{6} \mathrm{H}_{12} \mathrm{O}_{6} \rightarrow 2 \mathrm{C}_{2} \mathrm{H}_{5} \mathrm{OH}+2 \mathrm{CO}_{2}+\text { Energy }
$$

However, this is a simplified equation as many flavor compounds are also produced as by-products. The product of this primary fermentation is called 'green beer'. This is an immature beer containing undesirable substances such as diacetyl, aldehydes and sulfur compounds which give the beer an unclean and unbalanced taste [1].

In order to reduce the levels of these undesirable flavor compounds, the beer must go through what is known as 'secondary fermentation', also referred to as maturation, conditioning or lagering. While these are traditionally thought of as two independent processes, in reality, there is a significant overlap. While the yeast has completed its primary goal of alcohol production during the first fermentation, during the maturation process it continues fermentation and removes the undesirable flavor compounds produced in that first stage. The main compound that is targeted in this process is diacetyl, a molecule with an intense buttery off-flavor. Diacetyl is metabolized to 2,3-butandiol, a compound with a much higher flavor threshold than diacetyl, therefore having less impact on the overall flavor of the final beer [12]. The extent and rate of the removal of these compounds can be controlled by manipulating yeast concentration, temperature and levels of agitation. Generally, optimal yeast health, an increased temperature and an increased exposure of yeast to diacetyl (by, i.e., agitation) lead to an increased rate of diacetyl removal [12].

\subsection{Pitching}

The inoculation of wort with yeast cells is called 'pitching'. In a study by Verbelen et al. (2009), the degree to which yeast performance and final beer flavor were affected by pitching rate was investigated. It was found that while a higher initial cell count leads to a faster fermentation, there were limited physiological and metabolic differences observed in the yeast cells in a higher density. The main difference came in the enhanced diacetyl levels in the beers with a higher pitching rate [13]. In contrast to this, a study by Kucharczyk and Tuszyński (2015), showed a similar increase in fermentation rate but no significant difference in the levels of diacetyl produced [14]. Serial re-pitching of the yeast can also have an effect on the final beer composition. It has been shown that the polypeptide profile of the beer is directly influenced by the generation of yeast used in inoculation [15].

\subsection{Yeast Viability}

Beer quality is greatly influenced by the biochemical performance of the yeast and therefore it is important for brewer's to be able to accurately predict yeast viability (also known as yeast vitality). In order to optimize fermentations, it is vital to determine yeast viability in order to adjust the pitching rate accordingly [16]. Most commonly, methylene blue staining is used to determine the health of the yeast cells. Yeast cells that are viable contain an enzyme that decolorizes the methylene blue stain [17]. Therefore, it is easy to distinguish between living and dead cells under the microscope; live cells are colorless whereas dead cells remain stained. While methylene blue staining is the most commonly accepted method for determining yeast viability, a study by Smart et al. (1999) investigated and proved the use of citrate methylene violet staining as an alternative method of determining yeast viability [18]. Similarly, in a study by Bouix and Leveau, (2001), a flow cytometric method was used to monitor efflux percentage of yeast cells during fermentation. The results showed that the efflux percentage is a reliable indicator of cell energy and vitality [16]. 


\section{Formation and Processing of Brewer's Spent Yeast (BSY)}

In order to utilize to their full extent the nutrients and functional ingredients within the yeast cells, the BSY must be separated effectively from the bulk, followed by processing into yeast extract and other yeast products.

\subsection{Flocculation}

Flocculation is defined as the tendency of yeast cells to associate with one another [10]. This allows for easier removal of the yeast from the 'green' beer at the end of fermentation from the top or the bottom of the vessel, depending on yeast type. It is crucial that yeast flocculation occurs at the correct time, towards the end of the bulk fermentation in the brewing process. Premature flocculation or incomplete flocculation may negatively impact the fermentation process leading to a slower, 'sluggish' fermentation [19]. Yeast flocculation is a highly complex phenomenon, influenced by the expression of yeast flocculation genes, namely, FLO1, FLO5, FLO8 and FLO11 [8]. However, these genes are highly variable and differ from one yeast strain to the next. Flocculation is also impacted by factors which affect the composition and morphology of the cell wall, including nutrient availability, dissolved $\mathrm{O}_{2}$ levels, fermentation temperature and yeast handling and storage conditions. Conditions that increase cell collisions within the medium (i.e., agitation) can also have an effect on flocculation [8].

\subsection{Production of Yeast Extract}

In order to access the yeast components with the most potential for food and nutraceutical applications, surplus yeast may be processed into yeast extract. Yeast extract is defined as the soluble content of a yeast cell that remains once the cell wall has been destroyed and removed [20]. The method chosen to disrupt the yeast cell wall can have an impact on the future composition of the yeast extract. There are mechanical methods including using the cell mill or sonotrode, as well as non-mechanical methods such as autolysis. On an industrial scale, non-mechanical methods are most frequently used.

The methods of manufacturing yeast extracts can be divided into autolysis and hydrolysis. Yeast hydrolysates are yeast extracts prepared with the addition of hydrochloric acids or proteolytic enzymes. Yeast autolysis is the self-digestion of the cell by its endogenous enzymes and occurs naturally at the end of the cell's life cycle. During autolysis, proteins, glycogen, nucleic acids and other cell components are degraded [9]. These endogenous enzymes consist of cell proteases, nucleases, glucanases and phospholipases [21]. Autolysis of the yeast cell is triggered when the cell growth cycle is completed and the death or decline phase begins. These intracellular enzymes lead to partial degradation of the yeast cell wall, allowing extraction of the valuable materials including proteins, vitamins and carbohydrates without damaging their native structure [22]. The temperature at which autolysis occurs is highly important, with $50{ }^{\circ} \mathrm{C}$ for $24 \mathrm{~h}$ being deemed desirable in terms of content and yield of protein and $\alpha$-amino nitrogen [23]. Plasmolysis refers to a modified autolysis process, with the addition of 'accelerators' to aid cell breakdown. These accelerators include inorganic salts and organic solvents. There are some disadvantages to yeast autolysis including low extract yield, difficult phase separation due to the high amount of residue in the autolysate, an increased risk of microbial contamination and poorer sensory characteristics [24].

In a study by Jacob et al. (2019), various methods of yeast cell wall disruption and their effects on yeast extract composition were investigated [25]. A cell mill was used as the mechanical method of cell wall disruption and autolysis was used as the non-mechanical method. Autolysis was induced by heating the material to $50{ }^{\circ} \mathrm{C}$ and holding for $24 \mathrm{~h}$, following the addition of sodium chloride and ethyl acetate at the beginning of the process [25]. Cell disruption via cavitation was also carried out using an ultrasonic sonotrode. After disruption, the cell walls were then separated from the internal elements of the yeast cell via centrifugation. It was observed that for many amino acids that play a key role on the aroma properties of a beer, release is most effective as a result of autolysis. These amino acids include leucine, isoleucine, valine, histidine, proline, cysteine and glutamine. This study showed 
that the method of preparation of yeast extract can have an impact on the amount of free amino acids as well as the protein fraction after processing. However, due to the diversity of the starting material, comparison between differing BSY sources is difficult [25].

Other novel processing methods have been investigated, including a combination of autolysis, enzymatic hydrolysis and selective membrane filtration. The production of brewer's spent yeast fractions by ultrafiltration was investigated by Amorim et al. (2016). One hundred liters of brewer's spent yeast autolysate was filtered and dehydrated by lyophilization to give $1 \mathrm{~kg}$ of dry matter. Four different fractions were obtained, each of different sizes and molecular weights, as well as differing nutritional compositions [26]. While very little literature exists exploring this method of yeast processing, it could potentially be used to create targeted fractions, each with a differing composition and therefore differing potential uses.

\subsection{Modification of Yeast Extract: Debittering}

A challenge that stands in the way of yeast extract production from brewer's spent yeast is the strong, bitter flavor associated with the brewery waste. Bitter substances arising from hops, namely, iso- $\alpha$-acids (such as humulones and iso-humulones), tannins and resins, adsorb onto the yeast cell walls during fermentation $[27,28]$. Generally, these compounds are removed by washing with alkaline or organic solvents prior to the extraction process. However, these methods of debittering are not economical and require the cells to be cleaned with water, creating a large amount of wastewater. A study by Shotipruk et al. (2005) investigated the potential for using alternate methods of debittering brewer's spent yeast [28]. It was discovered that, since the bitter substances adsorb solely onto the cell wall, debittering of spent brewer's yeast may be combined with cell debris separation. The effect of homogenization of the spent yeast prior to separation was also investigated. While the protein transmission and debittering efficiency were higher for the homogenized autolysate, there was still a strong bitter flavor when compared to cells washed with an alkaline solution. This is theorized to be due to the release of bitter substances from ruptured cell walls, as a result of the homogenization [28]. A high $\mathrm{pH}(\mathrm{pH} 10)$ in combination with a heat treatment, over $50{ }^{\circ} \mathrm{C}$, maximized the solubilization of the bitter constituents as debittering is more profound at higher temperatures [29]. In terms of residual yeast composition, the debittering process does not appear to cause any significant compositional difference between raw spent brewer's yeast and debittered brewer's yeast [29].

\section{BSY Composition and Properties}

Brewer's spent yeast is most commonly used in the food industry as either a flavor enhancer or as a nutritional supplement. Due to its high nutritive value, it has many potential uses in the functional food industry.

\subsection{Protein}

Brewer's spent yeast is a high-protein by-product. It contains $45-60 \%$ protein and is generally regarded as safe (GRAS). In a study by Vieira et al., 2016, BSY was found to contain 64.1\% protein (dry weight) with a high percentage of essential amino acids as seen in Tables 1 and 2. It was determined that $40 \%$ of the total amino acid count was comprised of essential amino acids [20]. The levels of essential amino acids are in line with the requirements set out by FAO/WHO (1990) for adult humans [30]. Generally, the sulfur (S-) containing amino acids (methionine and cysteine) are the limiting factors in the amino acids composition but in this study it was found that S-amino acids were above the target set by the FAO/WHO [20]. A high level (34\%) of flavor-enhancing amino acids was also determined, namely, glutamic acid, aspartic acid, glycine and alanine. A high level of these particular amino acids presents the potential of BSY or BSY extracts as flavor-enhancing ingredients. 
Table 1. Chemical Composition of Brewer's Spent Yeast.

\begin{tabular}{|c|c|c|c|c|c|c|}
\hline Chemical Composition & $\begin{array}{l}\text { Vieira et al. (2016) } \\
\text { (g/100 g dw) }\end{array}$ & $\begin{array}{l}\text { Cabellero-Cordoba and } \\
\text { Sgarbieri (2000) (\%) }\end{array}$ & Saksinchai et al. (2001) $(\% w / w)$ & $\begin{array}{l}\text { Marson et al. } \\
(2020)(\% \mathrm{dw})\end{array}$ & $\begin{array}{l}\text { Mathias et al. } \\
\text { (2015) (\% dw) }\end{array}$ & $\begin{array}{c}\text { Jacob et al. } \\
(2019)(\mathrm{g} / 100 \mathrm{~g})\end{array}$ \\
\hline Protein & $64.1+/-0.2$ & 47.19 & n.d. & 40.8 & 45.6 & $74.3+/-0.5$ \\
\hline$\alpha$-amino nitrogen & $12.9+/-0.1$ & n.d. & $4.5+/-0.2$ & n.d & $4.09+/-0.04$ & $5.81+/-0.10$ \\
\hline Ash & $14.0+/-0.2$ & 8.55 & $13.3+/-0.7$ & $7.0+/-0.1$ & $5.9+/-0.05$ & $13.5+/-2.3$ \\
\hline Fat & $1.32+/-0.04$ & 3.53 & n.d. & 0.21 & n.d. & $0.67+/-0.01$ \\
\hline Moisture & $7.70+/-0.12$ & n.d. & n.d. & n.d & n.d. & 6.8 \\
\hline Carbohydrate & $12.9+/-0.1$ & 21.52 & $26.8+/-0.3$ & n.d & n.d. & 14.7 \\
\hline RNA & $4.00+/-0.16$ & 7.04 & $\begin{array}{c}21.3+/-0.4 \text { (by orcinol) } \\
23.2+/-0.6(\text { by UV } 260 \mathrm{~nm})\end{array}$ & $1.9+/-0.1$ & n.d. & $5.518+/-0.10$ \\
\hline Soluble Fiber & n.d. & 9.65 & n.d. & $6.6+/-0.1$ & n.d. & n.d. \\
\hline Insoluble Fiber & n.d. & 2.57 & n.d. & & n.d. & n.d. \\
\hline
\end{tabular}

n.d. stands for 'not determined'; dw represents 'dry weight'.

Table 2. Mineral Composition of Brewer's Spent Yeast Extract [20,31,32].

\begin{tabular}{|c|c|c|c|}
\hline Macrominerals & Vieira et al. (2016) $\mathrm{mg} / 100 \mathrm{~g} \mathrm{dw}$ & Jacob et al. (2019) mg/100 g dw & RDA (FSAI) \\
\hline Sodium (Na) & $1228+/-22$ & $88.1+/-0.001$ & $1600 \mathrm{mg}$ \\
\hline Potassium (K) & $9148+/-69$ & $6248.7+/-0.001$ & $2000 \mathrm{mg}$ \\
\hline Calcium (Ca) & $27.1+/-0.40$ & $16.4+/-0.001$ & $800 \mathrm{mg}$ \\
\hline Magnesium (Mg) & $273+/-2.31$ & $210.2+/-0.001$ & $375 \mathrm{mg}$ \\
\hline \multicolumn{4}{|l|}{ Trace Elements } \\
\hline Chromium & $0.019+/-0.00$ & n.a. & $40 \mu \mathrm{g}$ \\
\hline Iron & $1.76+/-0.03$ & $3.672+/-0.01$ & $14 \mathrm{mg}$ \\
\hline Manganese & $0.564+/-0.013$ & $0.15+/-0.01$ & $2 \mathrm{mg}$ \\
\hline Cobalt & $0.030+/-0.001$ & $0.252+/-0.01$ & n.a. \\
\hline Molybdenum & $0.003+/-0.00$ & n.a. & $50 \mu \mathrm{g}$ \\
\hline Zinc & $11.9+/-0.29$ & $9.963+/-0.01$ & $10 \mathrm{mg}$ \\
\hline Copper & $0.364+/-0.001$ & $0.221+/-0.011$ & $1 \mathrm{mg}$ \\
\hline Selenium & $0.030+/-0.00$ & n.a. & $55 \mu \mathrm{g}$ \\
\hline
\end{tabular}

n.a.: not available; $d w$ : based on dry weight; RDA: recommended dietary allowance. 
In an earlier study by Caballero-Cordoba and Sgarbieri (2000), a protein content of $47.19 \%$ was determined. The amino acid profile of the Saccharomyces strain used in this study generally corresponds with the results obtained by Vieira et al. (2016) above. However, it was found that the limiting essential amino acid in this trial was lysine with only $5.69 \mathrm{~g} / 100 \mathrm{~g}$ available when the FAO/WHO standard is $5.8 \mathrm{~g} / 100 \mathrm{~g}$. Similar results were reported by Podpora et al. (2016), whereby the protein content in two yeast extracts from spent yeast was found to be $62.5-63.8 \%$ [2]. The amino acid profiles of these two extracts agree with other values found in literature. When compared to Saccharomyces cerevisiae and rootlets, another by-product of the brewing industry, BSY has a high level of essential amino acids, as seen in Figure 1.

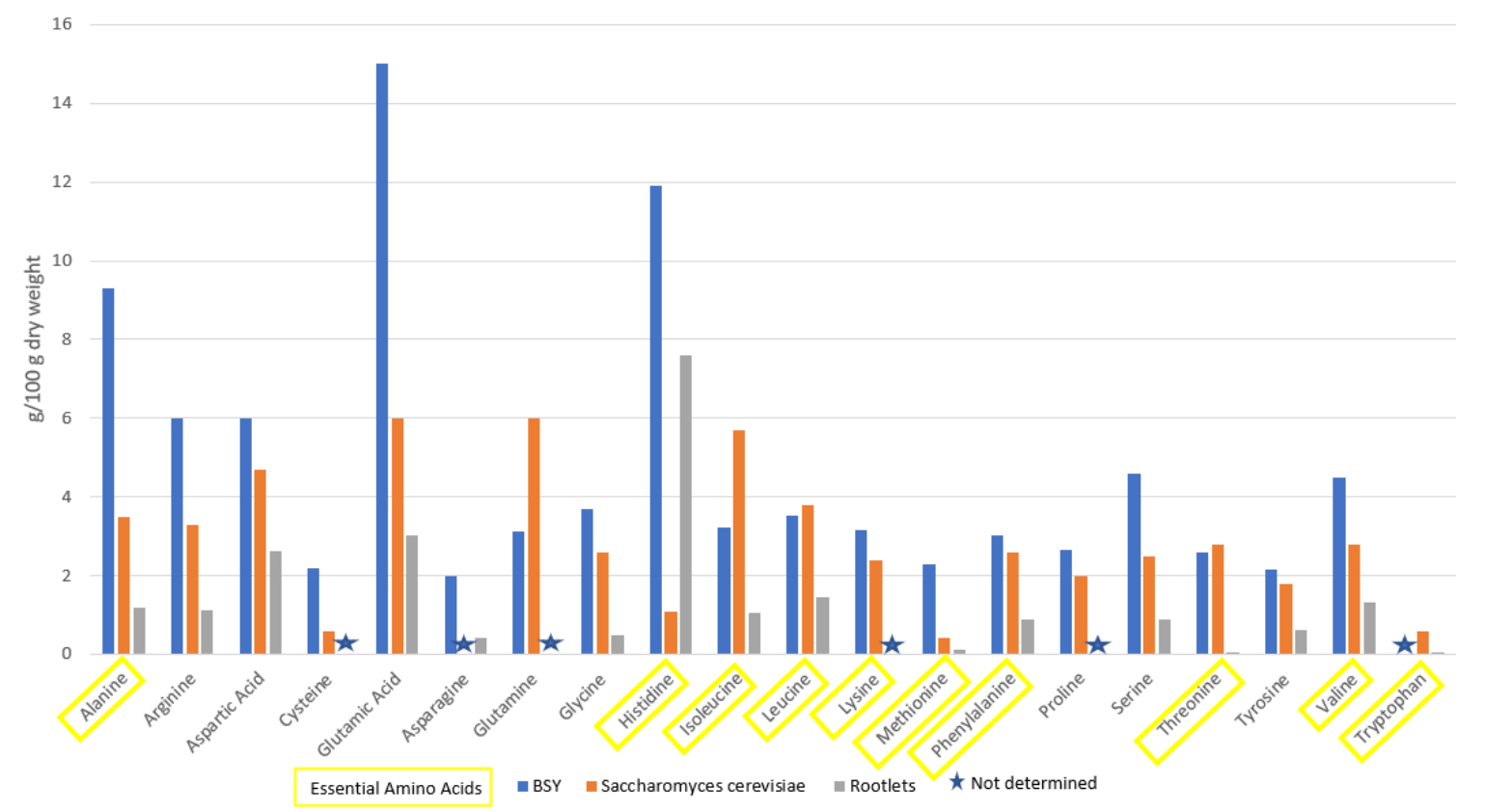

Figure 1. Amino Acid Profiles of Brewer's Spent Yeast (BSY) in comparison to Saccharomyces cerevisiae and rootlets, with the essential amino acids highlighted in yellow [20,33,34].

\subsection{Carbohydrates}

A high percentage of BSY polysaccharides are insoluble, approximately $83 \%$ of total polysaccharide content. Even following harsh alkaline treatment, they can only be partially solubilized, leaving an insoluble fraction of $24 \%$ of total polysaccharides [5]. BSY polysaccharides are mainly comprised of $\beta$-glucans, mannoproteins and glycogen. Chitin is also present in the cell walls in a small concentration but greatly contributes to the insolubility of the polysaccharides. In terms of Saccharomyces cerevisiae, the cell wall makes up about $25-50 \%$ of the volume and $15-30 \%$ of the dry weight of the cell [35]. According to Pinto et al. (2015), the cell wall consists of 50-60\% $\beta$-glucan, 35-40\% mannoproteins, $1-3 \%$ chitin and $1-23 \%$ glycogen [5].

The $\beta$-glucan component of the cell wall is comprised of mainly a $\beta-(1,3)$ glucan backbone (approx. $85 \%$ of yeast glucan component) and a minor $\beta-(1,6)$ glucan (approx. $3 \%$ of glucan component) [36]. $\beta$-glucans have been linked with many health benefits including pre-biotic, anti-inflammatory, anti-diabetic, anti-cancer and immune-modulating effects [5,37]. Functionally, $\beta$-glucans are also useful in altering the texture, mouthfeel and rheological properties of food products, as well as being effective stabilizers, emulsifiers and potential fat replacers [4,38]. Interestingly, when compared with commercially available $\beta$-glucans from baker's yeast, the BSY $\beta$-glucans exhibited a higher apparent viscosity, water holding capacity and increased emulsion stabilizing capacities [39]. Alkaline treatment is most commonly used as the method for $\beta$-glucan extraction and in a study by Thammakiti et al. (2004), it was discovered that homogenization can increase the effectiveness of $\beta$-glucan extraction 
as well as increasing the apparent viscosity [39]. This is theorized to be due to the fragmentation of the yeast cell walls. Glycogen, an $\alpha$-glucan, is present in two forms in the yeast cell wall: a soluble and an insoluble form. The latter due to a covalent linkage between glycogen and cell wall $\beta-(1,3)$ glucan via a $\beta-(1,6)$ linkage [40]. Mannoproteins, one type of glycoprotein, also present potential uses as emulsifiers in the food industry [41].

\subsection{Mineral and Vitamin Content}

In a study by Vieira et al. (2016), the mineral contents of brewer's spent yeast extract was determined by atomic absorption spectrometry (AAS) and inductively coupled plasma mass spectrometry (ICP-MS). This same method was also used by Jacob et al. (2019) to determine the mineral levels of an industrially produced spent yeast to use as a control in the examination of the effect of differing preparation methods on key extract characteristics [31]. A comparison of these studies is outlined in Table 2.

The sodium content was $1228 \mathrm{mg} / 100 \mathrm{~g}$ based on dry weight ( $\mathrm{dw}$ ) and the potassium content was $91.48 \mathrm{mg} / 100 \mathrm{~g} \mathrm{dw}$. These minerals play a key role in ribosomal protein synthesis as well as being essential in acid-base balance and water retention in the cell. A study by Jacob et al. (2019) showed a significantly lower sodium content, however, the levels of the other minerals in question were very similar to those determined by Vieira et al. (2016) [20]. Other elements are vital for bone development, muscle function, blood coagulation and neurological function. These include calcium and magnesium which are present at a levels of $27.11 \mathrm{mg} / 100 \mathrm{~g} \mathrm{dw}$ and $273.6 \mathrm{mg} / 100 \mathrm{~g} \mathrm{dw}$, respectively. According to the FSAI (2020), as described in the 2008 Council Directive [32], the recommended daily intake of calcium for adequate health is approx. $800 \mathrm{mg}$ per day, so at present BSY does not seem to be a significant source of calcium for the human diet, though it could contribute. However, the daily recommended intake of magnesium is 350-420 mg per day, so BSY could potentially be a very good source of magnesium, depending on the bioavailability of the mineral. This is also true of potassium with a recommended daily intake of $2000 \mathrm{mg}$. Magnesium plays an important role in the uptake and utilization of vitamins B and E as well as maintaining electrolyte and fluid balances [20]. Regarding trace elements, yeast extract could be a substantial source of these key nutrients, with mean iron levels of $1.76 \mathrm{mg} / 100 \mathrm{~g} \mathrm{dw}$, zinc levels of $11.9 \mathrm{mg} / 100 \mathrm{~g} \mathrm{dw}$, manganese levels of $0.564 \mathrm{mg} / 100 \mathrm{~g} \mathrm{dw}$ and copper levels of $0.364 \mathrm{mg} / 100 \mathrm{~g} \mathrm{dw}$, among others. These trace elements, while only required in very small concentrations, are essential in maintaining life.

Vieira et al. (2016) used HPLC to determine the levels of B vitamins in brewer's spent yeast extract. The results are outlined in Table 3. BSY is known as a good source of B vitamins, with high mean content of vitamin $B_{3}(72 \mathrm{mg} / 100 \mathrm{~g}), \mathrm{B}_{6}(55.1 \mathrm{mg} / 100 \mathrm{~g})$ and $\mathrm{B}_{9}(3.01 \mathrm{mg} / 100 \mathrm{~g})$. A similar study by Jacob et al. (2019) determined relatively similar values of an autolyzed industrial BSY product via the same method. However, the value for vitamin $\mathrm{B}_{6}$ was significantly different to that of Vieira et al. (2016). A study by Pinto et al. (2013) also examined the vitamin contents of residual brewer's yeast following alkaline treatment and lyophilization [42]. However, many of the results obtained by Pinto et al. (2013) are significantly lower than those determined by Vieira et al. 2016. In particular, the levels of nicotinic acid $\left(B_{3}\right)(77.2 \mathrm{mg} / 100 \mathrm{~g}$ vs $0.79 \mathrm{mg} / 100 \mathrm{~g})$ and pyridoxine $\left(\mathrm{B}_{6}\right)(55.1 \mathrm{mg} / 100 \mathrm{~g}$ vs $9.99 \mathrm{mg} / 100 \mathrm{~g})$. Vitamin $\mathrm{B}_{2}$ was also present at a level of $2.34 \mathrm{mg} / 100 \mathrm{~g}$ which contradicts the results from Vieira et al. where the level of $B_{2}$ was non-quantifiable. This could be due to the natural variation in BSY composition due to cell health or age, differing preparation methods or alternative analytical methods. The level of cyanocobalamin (vitamin $\mathrm{B}_{12}$ ) was non-quantifiable in both studies. Significant differences are also present between the figures detailed and the results obtained by Jacob et al. (2019). While the levels of vitamin $B_{3}, B_{9}$ and $B_{12}$ were quite similar, the levels of pyridoxine and riboflavin were significantly different in comparison. 
Table 3. Vitamin Composition of BSY extract.

\begin{tabular}{|c|c|c|c|c|}
\hline Vitamins & $\begin{array}{c}\text { Vieira et al. (2016) } \\
(\mathrm{mg} / 100 \mathrm{~g})\end{array}$ & $\begin{array}{c}\text { Jacob et al. (2019) } \\
\mathrm{mg} / 100 \mathrm{~g} \mathrm{dw}\end{array}$ & $\begin{array}{l}\text { Pinto et al. (2013) } \\
(\mathrm{mg} / 100 \mathrm{~g})\end{array}$ & RDA (FSAI) \\
\hline Thiamine & NA & $7.46+/-0.5$ & NA & $1.1 \mathrm{mg}$ \\
\hline Nicotinic acid (B3) & $77.2+/-1.1$ & $78.6+/-2.0$ & $0.79+/-0.06$ & $16 \mathrm{mg}$ \\
\hline Pyridoxine (B6) & $55.1+/-2.5$ & $5.90+/-0.5$ & $9.99+/-0.06$ & $1.4 \mathrm{mg}$ \\
\hline Folic Acid (B9) & $3.01+/-0.02$ & $5.29+/-0.1$ & $0.25+/-0.03$ & $200 \mu \mathrm{g}$ \\
\hline Riboflavin (B2) & NQ $(0.329)$ & $10.6+/-0.5$ & $2.34+/-0.03$ & $1.4 \mathrm{mg}$ \\
\hline Cyanocobalamin (B12) & NQ $(0.256)$ & $0.16+/-0.1$ & NQ & $2.5 \mu \mathrm{g}$ \\
\hline
\end{tabular}

dw: based on dry weight; NQ: not quantified; RDA: recommended dietary allowance.

\subsection{Phenolic Compounds}

Phenols are compounds which contain a hydroxyl $(-\mathrm{OH})$ group bound directly to an aromatic ring. Polyphenols are phenols which contain more than one hydroxyl group. Polyphenols are of significant interest to the food and nutraceutical industries due to their antioxidant properties. Vieira et al. (2016) separated thirteen phenolic compounds from BSY via HPLC. Two compounds (gallic acid and $( \pm)$-catechin) were quantified in the yeast-free fraction whereas in the bound fraction, six compounds were quantified. (+)-catechin was the most abundant with $24.6 \mathrm{mg} / 100 \mathrm{~g} \mathrm{dw}$, followed by protocatechuic acid (13.1mg/100 g dw), p-coumaric acid (10.3 mg/100 g dw), ferulic acid (9.22 mg/100 $\mathrm{g} \mathrm{dw})$, gallic acid $(2.11 \mathrm{mg} / 100 \mathrm{~g} \mathrm{dw})$ and cinnamic acid (1.24 mg/100 $\mathrm{g} \mathrm{dw})$ [20]. The remaining four compounds were not detected. The levels of these polyphenols can be affected by temperature, the nature of extraction and the method of separation. A lyophilization pre-treatment, prior to the extraction of polyphenols, leads to a reduced yield of gallic acid, $p$-coumaric acid and naringin due to losses or transformations during vacuum drying. Similarly, the use of filtration also caused significant polyphenol losses and is therefore unsuitable for use as a separation method [43].

\subsection{Glutathione}

Glutathione, also known as GSH, is a compound found in plants, animals and fungi with significant antioxidant and other metabolic properties. It is an endogenous peptide, comprised of glutamate, cysteine and an additional amino acid with a low molecular weight, possibly serine or glycine [44,45]. It is known that certain yeast species can produce significant amounts of glutathione during fermentation. Glutathione in yeasts is formed by metabolization of glucose to pyruvate, followed by pyruvate and Acetyl-CoA entering the citric acid cycle (TCA). Glutamate is formed during this process and then combines with two other amino acids, one of which is cysteine, to form glutathione [45]. In a study by Liu et al. (1999), the optimal conditions for glutathione production by Saccharomyces cerevisiae were studied. It was discovered that glucose was the best carbon source for GSH production while fructose and sucrose lead to increased yeast growth. A combination of peptone and yeast extract was found to be the most efficient nitrogen source for GSH production by S. cerevisiae [46].

\section{BSY Applications}

BSY, in its raw and processed forms, has had very limited applications to date. While many potentially exciting technologies have been investigated, few have been implemented on an industrial scale, with animal feed being the main outlet for BSY currently. Figure 2 provides an overview of the current and potential applications of BSY. 


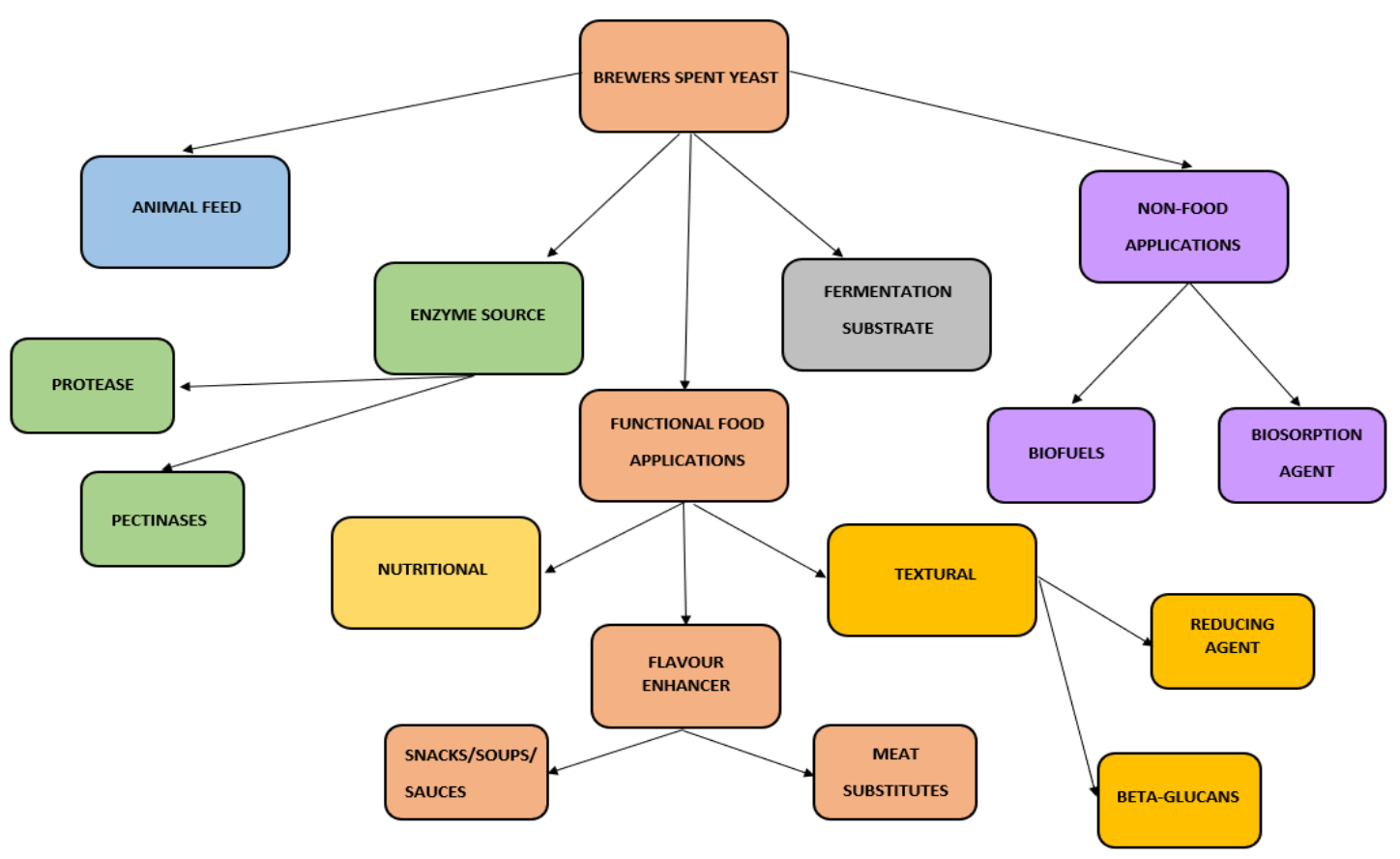

Figure 2. Overview of Current and Potential BSY Applications.

\subsection{Animal Feed}

Currently, the most well known and commonly used outlet for brewer's spent yeast is as a constituent of animal feeds, mainly as a cheap source of protein as well as a source of minerals and $B$ vitamins. The spent yeast may be incorporated as a wet slurry or can be dried before feeding. The addition of yeast to animal feeds has been shown to have positive effects on feed quality and feed utilization.

In ruminant animals, in addition to a nutritional benefit, it has been shown that the addition of yeast to the bovine diet can have a positive effect, including increased milk production and improved digestion. In a study by Wohlt et al. (1998), it was determined that the supplementation of bovine feed with 10-20 g per day of yeast can improve milk yield significantly. It is theorized that this is due to the effects of yeast metabolites produced within the rumen and their subsequent interaction with other rumen microbes [47]. It has also been shown that the addition of yeasts to ruminant diets as a probiotic can improve the gut microflora of the animal, especially in situations where sub-therapeutic antibiotic treatment is frequently used. This improvement in gut health can lead to increased fiber digestibility, increased weight gain and reduced methane production [48]. A study by Harlow et al. (2016) also investigated the effects of incorporating BSY into ruminant caprine feed. The primary focus of this study was to determine whether the increased hops levels in modern craft beer could have a beneficial effect on the animal through the spent yeast. Due to the increased level of hops, a high level of $\alpha$-and $\beta$-acids are present in the yeast and these compounds may act as antimicrobials, particularly inhibiting hyper ammonia producing bacteria (HAB). These bacteria cause major amino acid degradation, leading to a loss of valuable proteins. This study showed that the hops acids in the BSY protected proteins from degradation by HAB [49]. However, this was only shown in vitro so it is unclear if the same effect would be noted in live animals. Regardless, it does show potential for further study into rumen-protected proteins. It has also been shown that cost reduction in the sheep diet can be achieved by substitution of dried BSY for up to $100 \%$ of cornmeal in the feed formulation with no observable adverse effects on digestibility or feeding behavior [50].

There have also been several studies into the effect of yeast addition in poultry diets. In a study by Line et al. (1998), the effect of adding a yeast (Saccharomyces boulardii) to the animals diet was investigated. The key focus of this study was to reduce the frequency of gut colonization with pathogenic bacteria, 
namely Salmonella and Campylobacter. Salmonella is responsible for a high level of human foodborne infection and poultry is known to act as a reservoir for these types of pathogens. The broiler chickens were fed varying amounts of the yeast and were challenged by 'seeder' birds, animals known to carry pathogens. It was observed that there was a decreased frequency of Salmonella colonization in the animals that had been fed the yeast-supplanted diet while the frequency of colonization of Campylobacter in all animals was unaffected. While it is unclear exactly how this occurs, it is theorized to be due to the presence of the sugar mannose in the yeast cell wall. Certain pathogens, including Salmonella, have an affinity to bind to mannose and therefore the mannose in the yeast cell could act as a bacterial inhibitor, preventing the pathogen from adhering to the intestinal cell wall. There was also no observed statistically significant change in animal weight [51]. However, in other studies, an increase in weight in addition to overall health was noted [48].

The addition of yeast into the diet of an animal for meat production can have a positive effect on meat quality. In a study by Milewski et al. (2013), the effect of yeast addition to the diet in lambs was examined. An increase in positive meat performance indicators was observed, including body weight, daily gains, growth rate, muscle dimension and fat thickness. There was also a marked increase in humoral immunity indicators including, lysozyme, ceruloplasmin and gamma globulin [52].

Brewer's spent yeast as animal feed has also been considered in aquaculture. Aquafeeds are generally heavily reliant on marine ingredients such as fish meal and oils [53]. In a study by San Martin et al. (2020), the potential of BSY as a replacement for fishmeal is explored. Due to its plentiful availability and its low cost, as well as its nutrient density, on paper, BSY presents itself as a viable option in formulating aquafeeds. The spent yeast used in this study underwent a pre-treatment to increase digestibility, including a hydrolysis step and an enhanced drying step, as it has a lower intestinal absorption rate than the typically used fishmeal. The results showed that the BSY had good digestibility and could potentially be used as a fishmeal alternative in aquafeeds. In a similar study, BSY was explored as an option to replace up to $60 \%$ of the diet of the giant freshwater prawn in different environments. There was no observable significant change in growth or survival from $0 \%$ substitution to $40 \%$ in either environment (clear water vs. biofloc system). However, an increase in fish growth was observed in the fish with $60 \%$ BSY substitution being raised in the biofloc system [54]. The effect of BSY feeding on fish digestive enzymes was investigated by Castro et al. (2013). In this study the effects of feeding 1-2\% BSY to two fish species (White sea bream and meagre) were investigated. The results showed that BSY feeding led to an increased level of amylase and protease activity in the pyloric caeca of the sea bream while in the meagre only amylase activity was increased. While the mean weight of the fishes was unaffected, the feed efficiency with the BSY supplementation was significantly increased for the meagre [55].

\subsection{Brewer's Spent Yeast as an Enzyme Source}

Brewer's spent yeast can also be used as a medium for the extraction of enzymes for use in other processes. A series of studies have looked into the use of BSY proteases in the production of Sardine Protein Hydrolysates from low-value sardine by-products. Vieira and Ferreira (2017) found that hydrolysates produced from sardine sarcoplasmic proteins via BSY proteases exhibited antioxidant and ACE inhibitory properties [56]. In addition to this, a separate study determined that treatment with BSY proteinases gave the sardine protein hydrolysates increased emulsion, foaming and oil-binding capacities [57]. It was also observed in a follow-up study that Sardine Protein Hydrolysates (SPH) produced using residual yeast proteinases can have an anti-inflammatory effect in an intestinal-endothelial co-culture cell model [58]. Although it is unclear exactly how this effect occurs, the results suggest that it is a combination of the bio-active compounds present in the hydrolysates as well as the influence of the metabolites produced by the Caco-2 cell peptidases. This exciting discovery could potentially be used in the treatment and prevention of inflammatory diseases; however, more research is required. The use of BSY proteases to produce brewer's spent grain (BSG) hydrolysates also resulted in protection of the target cells from free-radical cytotoxicity [59]. 
Residual brewer's yeast has been shown to be effective as a growth medium for lactic acid bacteria in the production of proteolytic enzymes. In a study by Mathias et al. (2017), three brewery wastes were investigated as alternative mediums for the cultivation of lactic acid bacteria to compare their potential for protease production. Residual yeast showed the most potential for the production of extracellular proteolytic enzymes, with a final purified proteolytic extract of $145.5 \mathrm{U} / \mathrm{g}$ of precipitated protein. The high level of proteins and the absence of carbon led the microorganism to release extracellular proteases easily, making BSY a good potential medium for protease production by lactic acid bacteria [60].

Saccharomyces cerevisiae can also be a source of pectinases for use in the extraction of fruit juices. Fruits high in pectin benefit from the addition of pectinases for a higher juice yield. Crude pectinases extracted from yeasts have been shown to be effective in significantly increasing the juice yields of pineapple and pawpaw [61,62]. Brewer's spent yeast could potentially be a low-cost and abundant source of these pectinases.

\subsection{Functional Food Applications}

\subsection{1. $\beta$-Glucans and Mannoproteins as Functional Food Additives}

Brewer's spent yeast $\beta$-glucans have demonstrated abilities in thickening and emulsifying as well as exhibiting a good water holding capacity and potential fat replacing capabilities. $\beta$-glucans are also nutritionally non-functional, meaning they are very low in calories. This is a very desirable characteristic for a functional food additive [38]. In a study by Thammakiti et al. (2004), the potential uses and extraction methods for BSY $\beta$-glucans as a functional food ingredient were investigated. The $\beta$-glucans were extracted from a BSY slurry by autolysis and homogenization followed by alkaline extraction. The characteristics of these ingredients were then characterized and compared to commercially available products. The $\beta$-glucans from BSY exhibited an increased apparent viscosity, increased water holding capacity and better emulsion stabilizing properties than the commercial products tested. However, the oil binding capacity was unaffected [39].

Spent yeast $\beta$-glucans have also been implemented in bakery products, such as bread. A $\beta$-glucan-rich flour (2.02 $\mathrm{g} \beta$-glucans $/ 100 \mathrm{~g}$ flour) was used to create loaves with a higher specific volume and a more uniform pore structure than the control loaf [63]. This could be due to the stabilizing effect of the $\beta$-glucans on the gas cells in the dough, similar to the effect of other cereal $\beta$-glucans on bread dough. The $\beta$-glucan-rich loaf also had an increased fiber content $(+39 \%)$ which adds certain nutritional benefits related to gut health and motility. In the same study, the effect of proteins/proteolytic enzymes as bread additives was also explored, but with less successful outcomes. The proteolytic enzymes degraded the gluten structure leading to a decreased specific volume and little significant functional or nutritional gain from the additional protein. There is very limited literature regarding the application of brewer's spent yeast and in cereal products.

Studies by Silva Araújo et al. (2014) and Worrasinchai et al. (2006) investigated the use of spent yeast $\beta$-glucans and mannoproteins as a fat-replacing and emulsion stabilizing ingredient in mayonnaise. In the first study, mannoproteins were used to replace xanthan gum as an emulsifying and stabilizing agent. No negative effect on the sensory properties of the mayonnaise were detected by the sensory panel, even after prolonged storage [4]. This study showed that BSY mannoproteins have potential in the food industry as a synthetic emulsifying and stabilizing agent. The potential uses of yeast mannoproteins as bio-emulsifies was also explored by [41]. Worrasinchai et al. (2006) used yeast $\beta$-glucans to replace oil in a reduced fat mayonnaise at levels of $25 \%, 50 \%$ and $75 \%$ substitution. As fat is a key textual component of many foods, particularly high-fat foods such as mayonnaise, a low-calorie alternative to oil would be extremely useful in low-fat food product development. In contradiction to the previous study, sensory characteristics of the reduced fat mayonnaise were slightly reduced. However, levels of up to $50 \%$ substitution of oil for $\beta$-glucan were deemed acceptable by a sensory panel [38]. 
A study by Pancrazio et al. (2016) investigated the use of BSY extract in cooked hams as a potential textural agent and flavor compound. The results showed that $1 \%$ BSY extract addition significantly increased hardness and chewiness, as well as protein and free amino acid levels in comparison to the control hams. While more research is required, these results show the potential of BSY extract as a gel stabilizer in hams, potentially improving sliceability and water holding capacity [64].

\subsubsection{Reducing Agents}

As described earlier in this review, yeast cells are a good source of glutathione, a tri-peptide antioxidant compound [44]. Glutathione, as well as cysteine, can be used as reducing agents in the production of bread dough. Reducing agents are used in dough formulations to reduce mixing time, increase dough elasticity, and improve extensibility. In a bread dough, the structure and 'strength' of the system is determined by the formation of di-sulfide (-SS-) bonds. Reducing agents work by disruption these bonds, therefore weakening the dough structure [65]. In a study by Yano (2012), reduced glutathione improved the gas retaining properties of a gluten free rice batter dough in a yeast leavening process [66]. Verheyen et al. (2015) explored the destabilising effect of reducing agents on wheat doughs, including cysteine and reduced glutathione. The results showed a reduced dough development time and an increase in softness of the dough as a result of free thiol (-SH) groups [67]. Due to the presence of significant amounts of glutathione and cysteine in BSY, there is potential for the application of BSY in dough production as dough improvers.

\subsubsection{Health and Nutritional Applications}

\section{B-Glucans}

In addition to use as a functional ingredient, yeast $\beta$-glucans can be used as an ingredient to deliver a health benefit. $\beta$-glucans contain a specific combination of $\beta-(1 \rightarrow 4)$ and $\beta-(1 \rightarrow 3)$ linkages, creating long chain polysaccharides with a high molecular weight. These generate viscosity in the gut and this is believed to be the main reason behind the health benefits of $\beta$-glucans [68]. The perceived health benefits of $\beta$-glucans include stimulating and modulating the immune system, improving blood cholesterol levels and reducing the postprandial glucose response, improving satiety [68,69]. The effect of BSY and extracted $\beta$-glucans on lipid metabolism was examined in rats. Two ingredients were fed to rats in differing doses, with one group receiving $50 \mathrm{mg} / \mathrm{kg}$ dried BSY daily and the other receiving 10/100 $\mathrm{mg} / \mathrm{kg} \beta$-glucans which had been extracted from the residual yeast. At the end of the study, both groups showed a significant reduction in the concentration of total cholesterol as well as LDL-cholesterol and triacylglycerols in the blood when compared to the control [70]. In a study conducted by Bell et al. (1999), the effects of $\beta$-glucans from yeast and oats on serum lipids was investigated. It was determined that both oat-derived, and yeast-derived $\beta$-glucans reduce serum cholesterol levels in the blood. The yeast $\beta$-glucans may be more efficient due to the higher concentration of $\beta$-glucan in the derivative $(86 \%)$ when compared to the oat $\beta$-glucan extract $(15.9 \%)$. Yeast $\beta$-glucans and oat $\beta$-glucans also differ significantly in other ways, including $\beta$-linkages. Oat $\beta$-glucan is a polysaccharide comprised of $\beta-(1 \rightarrow 4)$ linked glucose units separated by $\beta-(1 \rightarrow 3)$ linked glucose every one to three units, whereas yeast $\beta$-glucans comprise of a $\beta-(1 \rightarrow 6)$ branched, $\beta-(1 \rightarrow 3)$ polysaccharide [71]. It is important to note that both the $\beta$-glucan source and extraction method can have a significant impact on key $\beta$-glucan characteristics, namely structure and molecular weight [72]. Molecular weight has an impact on the gelling capacity of the $\beta$-glucan, where a low molecular weight exhibits a better gelling capacity and a larger molecular weight, poorer gelling capacity [73]. A study by Salgado et al. (2017) compared the capabilities of both yeast $\beta$-glucan and barley $\beta$-glucan in producing aerogels for drug delivery. It was determined that yeast $\beta$-glucans had increased stability and elasticity, a stronger resistance against compression stress and a high water absorption capacity [73]. 


\section{Encapsulating Agent}

BSY has also shown potential as a starting material to be used as an encapsulating agent. In a study by Marson et al. (2020), Maillard-treated BSY cell debris was used as an encapsulating agent for ascorbic acid, a commonly used but highly unstable ingredient used widely in the food industry. The yeast material was prepared by enzymatically hydrolyzing Saccharomyces species from Lager Pilsen beer production. The enzymes used were Alcalase, Protamex (from Novozymes) and Brauzyn (from Prozyn). A Maillard reaction was induced by heating the hydrolyzed cells in wet medium at $75^{\circ} \mathrm{C}$ for $12 \mathrm{hrs}$., followed by cooling in an ice bath. The Maillard reaction is a reaction between reducing sugars and amino acids. While it causes browning and the production of aroma compounds, it can also improve the functional properties of the protein, such as solubility [74]. Following this treatment, the mixture was spray dried in a mini spray drier, with a double-fluid-type atomizer nozzle. The microstructure and shape of the particles were examined using Scanning Electron Microscopy and the sample showed very similar properties to the control (particles produced without the addition of ascorbic acid) giving particles with a high encapsulation yield, a low water activity (Aw) and good hygroscopicity [74]. Fourier transform infrared technology was used to analyze the produced particles as well as the dried yeast cell wall debris, ascorbic acid, and maltodextrin (a commonly used encapsulation agent). This confirmed the presence of yeast cell debris on the particle surface, meaning that encapsulation was successful. This study shows the exciting potential of hydrolyzed BSY debris as an encapsulating agent but further research into particle viability and storage stability, as well as nutritional value, is needed.

\section{Cryoprotectant for Probiotic Bacteria}

Da Silva Guedes et al. (2019) investigated the possibility of using BSY $\beta$-glucans as a protectant for probiotic lactobacilli during freeze-drying, storage and in the gastrointestinal tract. In order for probiotics to have a positive health benefit, a high number of cells must reach the gut alive and viable, after having gone through the processing, storage and digestion processes. Yeast $\beta$-glucans were compared with fructooligosaccharides (FOS), an established cryoprotectant in their ability to protect the probiotic strains from degradation. The $\beta$-glucans used were extracted from brewery slurry using enzymatic treatments and sonication. It was found that the cryoprotectant properties of BSY $\beta$-glucans were very similar to those of FOS, making it an effective cryoprotectant for probiotic bacteria. However, after 90 days of storage, FOS showed superior protective abilities than the yeast $\beta$-glucan [75].

\section{Antioxidant Properties}

Yeast hydrolysates have potential as food or nutraceutical ingredients due to their antioxidant properties [76]. This antioxidant activity is due to the presence of a high level of polyphenolic compounds. Autolysis of the BSY can enhance total phenolic content (TPC), ferric reducing antioxidant power (FRAP) and ACE-inhibitory activity [77]. A study by Marson et al. (2019) investigated the effect of sequential enzymatic hydrolysis on the antioxidant properties of spent yeast. The results showed that, after enzymatic hydrolysis, internal cell components, including nutrients and enzymes, were more effectively released. This led to a $63 \%$ increase in antioxidant properties, as determined by FRAP and 1,1-diphenyl-1-picrylhydrazyl (DPPH) assays. Crude protein and total protein recovery were also improved by $50 \%$ and $83 \%$, respectively. The influence of re-pitching on the hydrolysis was also investigated and it was determined that it took the repatched yeast up to 3.5 times longer to reach the same level of hydrolysis as the non re-pitched yeast [78]. In comparison to liquid beer waste, BSY extracts have been shown to contain higher levels of polyphenols, antioxidants, and flavonoids, indicating BSY as a potential industrial source of polyphenols for the food and nutraceutical industries [43]. 


\subsubsection{Flavor-Enhancing Ingredient}

Yeast, in particular brewer's spent yeast, is known as good source of nucleotides due to its high RNA content (approx. 8-11\% of dry mass). Certain nucleotides, in particular 5'-monophosphates, are well-known flavor enhancers [79]. During autolysis, endogenous enzymes break down nucleic acids into nucleotides, creating $5^{\prime}$-nucleotides. They can also be partially hydrolyzed by the addition of enzymes, mainly $5^{\prime}$-phosphodiesterase [79]. Guanosine $5^{\prime}$-monophosphate is an active flavor enhancer and adenosine $5^{\prime}$-monophosphate is a precursor to inosine $5^{\prime}$-monophosphate, a flavor enhancer with 100 times the flavor-enhancing power than monosodium glutamate [80]. Differing processing methods can create a wide variety of flavor compounds in the spent yeast, as a result of interactions between amino acids, nucleotides, carbohydrates and peptides [81]. The flavors created in preparing yeast extracts are widely applicable in the food industry, in particular for meaty, 'umami' flavors. These flavors are produced by the synergistic action of $5^{\prime}$-nucleotides, glutamic acid and cysteine [81,82]. The flavor-improving capacity of glutamate can be improved by up to 10-15 times due to the addition of 5'-nucleotides [81]. Yeast extracts enriched in these compounds can be used to add savory meat and mushroom type flavors to soups, sauces, cheeses and other prepared foods. Thermal treatment can have a significant impact on the umami proteolytic compounds in a yeast extract, as explored by [83]. Thermal treatment can accelerate the breakdown of the yeast cells (autolysis) and can enhance the production of new aroma compounds through reactions such as the Maillard reaction. It was determined that a temperature of $110^{\circ} \mathrm{C}$ is the optimum temperature for producing umami peptides [83]. The heat-induced reaction between sulphureous amino acids (cysteine and methionine) and sugar is also known to create characteristically 'meaty' flavors [82]. As brewer's spent yeast is classified as a GRAS product, yeast extract can be used in food products safely and without an acceptable daily intake (ADI), making BSY a significant source of flavor-enhancing compounds for use in a wide variety of food products. Certain yeast extract fractions are in high demand from the food industry to be used in the manufacture of these flavor-enhancing compounds [26]. In order to produce these flavor-enhancing properties, the yeast cells must undergo cell degradation via autolysis or hydrolysis.

\subsubsection{The RNA Issue-Purines}

While these nucleotides can provide flavor-boosting properties, they also present some challenges. If the intake of yeast is relatively high, for example in the case of protein supplementation, the increased purine content can result in an increased uric acid levels in the blood, potentially leading to hyperuricemia and gout [3]. Generally, only a small amount of the purines in RNA are degraded into uric acid daily. An increase in uric acid in the body can be caused by on overabundance of purines in the diet but can also occur where there is an inherited genetic deficiency of purine salvage enzymes, such as hypoxanthine-guanine phosphoribosyl transferase (HPRT) and adenine phosphoribosyl transferase (APRT) as well as catabolic enzymes such as xanthine dehydrogenase (XDH) [84]. Degradation of RNA and the removal of the resulting mononucleotides needs investigation regarding the use of BSY as a significant ingredient in food products.

Several methods exist to degrade and/or remove nucleotides from yeast cells, though very limited literature exists on the application of these technologies to BSY. Some chemical methods for reducing the purine content of yeast cells includes undergoing alkaline hydrolysis or heat treatment in the presence of $\mathrm{NaCl}$, as seen in Table 4 [85]. A reduction of up to $53.1 \%$ of purines has been observed as a result of this method. Canepa et al. (1972) describe a method to significantly reduce the nucleic acid content of yeast involving yeast suspension in a $50 \mathrm{mM}$ phosphate solution, followed by a heat shock treatment, and dialysis/washing with phosphate solution. It was found that as a result of this treatment, 50-60 $\mathrm{g}$ of the treated yeast would only contain $1 \mathrm{~g}$ of nucleic acids, of which purines only comprised approx. $0.3 \mathrm{~g}$, well within an acceptable range [86]. It would be extremely interesting to see if a similar method would be so successful if used on brewer's spent yeast. The use of a heat shock step in the degradation of RNA is also described by Wiebe (2002). In this case, the yeast cells are heated to 
64-65 ${ }^{\circ} \mathrm{C}$ for $20-30 \mathrm{~min}$. This causes the RNA to degrade into monomers that can then diffuse out of the cell and be separated by centrifugation or similar technologies [87]. While this leads to the loss of other elements of the fungal biomass, it could still potentially be applied to BSY. Several autolytic methods for RNA reduction in yeast have also been investigated. These revolve around the use of the cells intracellular enzymes to degrade RNA. This process can be controlled by temperature and is more favorable in many situations than a chemical treatment [88]. Hydrolysis of the yeast cells has been shown to reduce RNA content by up to $33 \%$ when compared to a non-hydrolyzed sample [74].

Table 4. Reduction of Purines in Yeast Cells by Applying Heat Treatment in the Presence of NaCl; adapted from Trevelyan et al. (1976) [85].

\begin{tabular}{cccccc}
\hline Sample & $\begin{array}{c}\text { Suspension } \\
\text { Medium }\end{array}$ & $\begin{array}{c}\text { Total Solids } \\
\text { Recovery } \mathbf{( \% )}\end{array}$ & $\begin{array}{c}\text { Guanine } \\
(\mu \mathbf{m o l} / \mathbf{g})\end{array}$ & $\begin{array}{c}\text { Adenine } \\
(\mu \mathbf{m o l} / \mathbf{g})\end{array}$ & $\begin{array}{c}\text { Total Purines } \\
\text { as RNA (\%) }\end{array}$ \\
\hline & Water & 73.8 & 29 & 30 & 5.14 \\
& $1.0 \mathrm{M} \mathrm{NaCl}$ & 69 & 5.9 & 6.6 & 1.14 \\
Pressed yeast & Water & 69.4 & 24.4 & 25.4 & 4.62 \\
cells after & $0.4 \mathrm{M} \mathrm{NaCl}$ & 66.3 & 12.1 & 12.6 & 2.39 \\
autoclaving & $0.8 \mathrm{M} \mathrm{NaCl}$ & 66.1 & 4.5 & 4.8 & 0.91 \\
& $1.2 \mathrm{M} \mathrm{NaCl}$ & 66.8 & 3.2 & 4.2 & 0.71 \\
& $1.6 \mathrm{M} \mathrm{NaCl}$ & 67.2 & 2.6 & 3.3 & 0.57 \\
& $2.0 \mathrm{M} \mathrm{NaCl}$ & 69.1 & 3.9 & 3.4 & 0.7 \\
\hline
\end{tabular}

\subsubsection{Meat Substitute Applications}

In addition to providing flavorings in savory products such as soups and sauces, BSY also holds potential as a significant ingredient in the formulation of meat substitutes. A study by Gibson and Dwivedi (1970) examined the use of debittered and dried BSY, prepared by a modified alkaline wash process, as a base ingredient in the production of meat substitutes. Isolated soy protein was also added to enhance textural properties and increase protein content. The meat analogue production process was based on the unfolding of vegetable proteins via a heat treatment and the increased formation of cation bridges between these polypeptides via $\mathrm{pH}$ manipulation [89]. A follow-up study looking into the nutritional profile of BSY-based meat substitutes examined the protein quality of the product by completing growth studies in mice. The BSY-based meat analogue was substituted as the protein source in the diets at varying levels $(0 \%, 25 \%, 50 \%, 75 \%, 100 \%)$. The average weight gain and feed intake of the mice showed that the BSY-based meat substitute had very good protein digestibility and a good biological value. It was determined that the meat analogue, if substituted with methionine, would be of a similar protein quality to whole-egg protein or other high-quality animal proteins [90].

\subsection{Fermentation Substrate}

Due to its high nutritional value and low cost, BSY has shown potential for use as a fermentation substrate, as a means of providing nitrogen for microorganism growth. BSY also has a low carbon-to-nitrogen ratio which is desirable for an additive to fermentation media [91]. A study by Mathias et al. (2017) investigated the use of brewing by-products, including BSY, as growth media for the growth of lactic acid bacteria. Success was characterized by an increased acidity, as a result of lactic acid production by the lactic acid bacteria. BSY showed the most potential in the trial when compared to the other by-products tested. The addition of BSY extract on its own or in combination with other brewery by-products has a significant positive effect on lactic acid bacteria fermentation. Results suggest that BSY, in combination with other brewery by-products, can be a cost-effective fermentation medium for batch and fed-batch lactic acid fermentation [92]. Sawisit et al. (2012) produced succinate via Actinobacillus succinogenes and suggested that BSY extract could potentially be used as a nitrogen source for this process [93]. 


\subsection{Biofuels-Methane Production}

BSY is a brewing by-product containing high amounts of biodegradable organic matter [94]. Several studies have been conducted investigating the production of biofuel in the form of methane from the anaerobic fermentation of BSY. A study by Sosa-Hernández et al. (2016) compared the methane production of three different BSY samples (SY1, SY2 and SY3) and one sample (SY1) was examined in differing dilutions $(25 \%, 50 \%$ and $75 \%$ ) after an anaerobic digestion treatment. The results showed clear differences among the samples. While samples SY2 and SY3 produced a higher volume of gas compared to SY1 (665 mL, $360 \mathrm{~mL}$ and 80-117 mL, respectively), SY1 produced gas of a higher quality. As sample SY1 came from a source producing a 'hoppy' beer, the suspected inhibitory effect of hops could aid in explaining the difference in gas volume and composition between the three samples. The methane producing micro-organisms convert the readily available substrate from the sample while fermentation was inhibited by the hops, reducing the production of other gases $\left(\mathrm{CO}_{2}, \mathrm{H}_{2}\right.$ etc. $)$ [95]. A good-quality biogas should contain $50-80 \%$ methane so in this case, although the overall volume of gas produced by SY1 was smaller, the quality of the gas was more desirable. Similar existing studies reflect similar results to this, showing that BSY has potential as a biofuel-producing medium and could be used by breweries to offset on-renewable energy costs [96,97]. The inclusion of the brewery wastewater stream in the BSY fermentation has also been explored and does not seem to cause any negative effect on the biogas production. However, more research at a commercial scale is required [94,97].

\subsection{Biosorption Agent}

Brewer's yeast (Saccharomyces cerevisiae) has been shown to be an effective bio-sorbent. Yeast cells that have been specially modified using water-based magnetic fluid stabilized with perchloric acid have been shown to effectively aid in the biosorption and biodegradation of water-soluble dyes from wastewater streams [98]. The textile industry produces a large amount of wastewater containing dyes which would have a detrimental environmental impact if not removed. Since dead yeast cells appear to have increased biosorption efficacy, BSY could present a suitable source for these materials.

Yeast cell biomass has also been shown to be efficient in absorbing and removing heavy metals, such as chromium, lead and uranium, from wastewater streams [99,100]. The removal of toxic contaminants from industrial waste is incredibly important to minimize environmental damage, as the release of these compounds into the environment would have a significant negative impact on marine wildlife and eco-systems. The natural capacity of the yeast cells to flocculate gives a fast, easy and cheap method of separation, without the need for an energy input [101]. While little research exists on the application of these methods for industrial wastewater treatment, the use of a cheap, abundant material such as BSY to sequester heavy metals from wastewater streams is a very promising technology.

\subsection{Supplementation of Ethanol Fermentation}

A limited number of studies exist exploring the effect of BSY supplementation on ethanol fermentation. Brewer's spent yeast contains high levels of nitrogen and essential minerals, aiding the growth of fermenting yeast. In comparison to the use of yeast extracts and peptone, more commonly used nutritional supplements for fermentations, the results were very similar [102]. Supplementation of high-gravity fermentations with spent yeast (wet and/or dry) leads to a higher ethanol concentration and a significant acceleration in fermentation time, with the final stages of fermentation being reached after only $48 \mathrm{~h}$ as opposed to approx. $70 \mathrm{~h}$ in the un-supplemented fermentation. However, there were some manufacturing issues as a result of BSY addition. The increase of hydrocolloids because of the BSY addition caused a significant increase in the viscosity of the mash. However, this could be controlled by altering BSY addition or further treatment [103]. 


\section{Conclusions}

In recent years, there has been increasing interest in sustainability, in particular the reuse and valorization of food processing by-products. Brewer's spent yeast is of particular interest in this regard as it is produced in huge volumes as a by-product of the brewing industry. Spent yeast is currently extremely underutilized and has limited outlets, mainly being used in animal feed formulations. Due to its nutritive value and physical properties, there is evidence that residual yeast has untapped potential in a variety of applications, including functional food ingredients. There is also potential for use as a nutritional supplement in human and microbial nutrition as well as a raw material for enzyme production, biofuel production and as a biosorption agent. The incorporation of brewer's spent yeast in such applications is a very cost-effective prospect, while also reducing the volume of waste associated with the brewing industry.

Brewer's spent yeast is high in protein as well as minerals and vitamins, making it an attractive ingredient for food products to enhance nutritional value. Due to its high level of $\beta$-glucans, it also presents the possibility for use as a textural agent, a stabilizer or a gelling agent. However, the limiting factor preventing the use of a significant proportion of BSY in food products is the high level of RNA nucleotide bases, namely purines, present in the raw material. Excessive consumption of purines may lead to increased uric acid in the blood stream which has detrimental effects on human health. While this is a significant hurdle, it is possible to remove purines via additional processing such as heat, enzyme or alkaline hydrolysis treatments but further study must be carried out on the application of these technologies to brewer's spent yeast.

In essence, brewer's spent yeast is an underutilized brewing by-product with a variety of exciting potential applications in the food industry and beyond. Increased awareness of this potential may instigate further research into these new applications and create new opportunities for their exploitation.

Author Contributions: Conceptualization, A.W.S. and E.K.A.; writing—original draft preparation, A.J.; review and editing, A.W.S.; project administration, E.Z. All authors have read and agreed to the published version of the manuscript.

Funding: This project has received funding from the European Union's Horizon 2020 research and innovation programme under grant agreement No 818368. This manuscript reflects only the authors' views and the European Commission is not responsible for any use that may be made of the information it contains.

Acknowledgments: The authors would like to acknowledge Patrick O'Riordan. Gregory Belt, Steffen Muench and Thomas Monin for their input and scientific discussions.

Conflicts of Interest: The authors declare no conflict of interest.

\section{References}

1. Kunze, W. Technology Brewing and Malting, 2nd ed.; VLB Berlin: Berlin, Germany, 1999.

2. Podpora, B.; Świderski, F.; Sadowska, A.; Rakowska, R.; Wasiak-Zys, G. Spent brewer's yeast extracts as a new component of functional food. Czech J. Food Sci. 2016, 34, 554-563. [CrossRef]

3. Edozien, J.C.; Udo, U.U.; Young, V.R.; Scrimshaw, N.S. Effects of High Levels of Yeast Feeding on Uric Acid Metabolism of Young Men. Nat. Cell Biol. 1970, 228, 180. [CrossRef] [PubMed]

4. Araújo, V.B.D.S.; De Melo, A.N.F.; Costa, A.G.; Castro-Gomez, R.H.; Madruga, M.S.; De Souza, E.L.; Magnani, M. Followed extraction of $\beta$-glucan and mannoprotein from spent brewer's yeast (Saccharomyces uvarum) and application of the obtained mannoprotein as a stabilizer in mayonnaise. Innov. Food Sci. Emerg. Technol. 2014, 23, 164-170. [CrossRef]

5. Pinto, M.; Coelho, E.; Nunes, A.; Brandão, T.; Coimbra, M.A. Valuation of brewers spent yeast polysaccharides: A structural characterization approach. Carbohydr. Polym. 2015, 116, 215-222. [CrossRef] [PubMed]

6. Pinho, O.; Ferreira, I.; Santos, L.H. Method optimization by solid-phase microextraction in combination with gas chromatography with mass spectrometry for analysis of beer volatile fraction. J. Chromatogr. A 2006, 1121, 145-153. [CrossRef] [PubMed]

7. Bellut, K.; Arendt, E.K. Chance and Challenge: Non-Saccharomyces Yeasts in Nonalcoholic and Low Alcohol Beer Brewing-A Review. J. Am. Soc. Brew. Chem. 2019, 77, 77-91. [CrossRef] 
8. Verstrepen, K.J.; Derdelinckx, G.; Verachtert, H.; Delvaux, F.R. Yeast flocculation: What brewers should know. Appl. Microbiol. Biotechnol. 2003, 61, 197-205. [CrossRef]

9. Ferreira, I.; Pinho, O.; Vieira, E.; Tavarela, J. Brewer's Saccharomyces yeast biomass: Characteristics and potential applications. Trends Food Sci. Technol. 2010, 21, 77-84. [CrossRef]

10. Bamforth, C. Beer: Tap into the Art and Science of Brewing, 1st ed.; Insight Books: New York, NY, USA, 1998.

11. Lewis, M.J.J.; Young, T.W. Brewing, 1st ed.; Chapman \& Hall: London, UK, 1995.

12. Wainwright, T. Diacetyl-a review: Part i-analytical and biochemical considerations: Part ii-brewing experience. J. Inst. Brew. 1973, 79, 451-470. [CrossRef]

13. Verbelen, P.J.; Dekoninck, T.M.L.; Saerens, S.M.G.; Van Mulders, S.E.; Thevelein, J.M.; Delvaux, F.R. Impact of pitching rate on yeast fermentation performance and beer flavour. Appl. Microbiol. Biotechnol. 2009, 82, 155-167. [CrossRef]

14. Kucharczyk, K.; Tuszyński, T. The effect of pitching rate on fermentation, maturation and flavour compounds of beer produced on an industrial scale. J. Inst. Brew. 2015, 121, 349-355. [CrossRef]

15. Vieira, E.; Moura, C.; Almeida, T.; Meireles, S.; Brandão, T.; Pinho, O.; Ferreira, I. Influence of Serial Repitching on Beer Polypeptide Profiles. J. Am. Soc. Brew. Chem. 2012, 70, 275-279. [CrossRef]

16. Bouix, M.; Leveau, J.-Y. Rapid Assessment of Yeast Viability and Yeast Vitality During Alcoholic Fermentation. J. Inst. Brew. 2001, 107, 217-225. [CrossRef]

17. Painting, K.; Kirsop, B. A quick method for estimating the percentage of viable cells in a yeast population, using methylene blue staining. World J. Microbiol. Biotechnol. 1990, 6, 346-347. [CrossRef] [PubMed]

18. Smart, K.A.; Chambers, K.M.; Lambert, I.; Jenkins, C.; Smart, C.A. Use of Methylene Violet Staining Procedures to Determine Yeast Viability and Vitality. J. Am. Soc. Brew. Chem. 1999, 57, 18-23. [CrossRef]

19. Straver, M.H.; Aar, P.C.V.D.; Smit, G.; Kijne, J.W. Determinants of flocculence of brewer's yeast during fermentation in wort. Yeast 1993, 9, 527-532. [CrossRef]

20. Vieira, E.F.; Carvalho, J.; Pinto, E.; Cunha, S.; Almeida, A.A.; Ferreira, I. Nutritive value, antioxidant activity and phenolic compounds profile of brewer's spent yeast extract. J. Food Compos. Anal. 2016, 52, 44-51. [CrossRef]

21. Babayan, T.L.; Bezrukov, M.G. Autolysis in yeasts. Acta Biotechnol. 1985, 5, 129-136. [CrossRef]

22. Podpora, B.; Swiderski, F.; Sadowska, A.; Piotrowska, A.; Rakowska, R. Spent Brewer's Yeast Autolysates as a New and Valuable Component of Functional Food and Dietary Supplements. J. Food Process. Technol. 2015, 6, 6. [CrossRef]

23. Tanguler, H.; Erten, H. Utilisation of spent brewer's yeast for yeast extract production by autolysis: The effect of temperature. Food Bioprod. Process. 2008, 86, 317-321. [CrossRef]

24. Bayarjargal, M.; Munkhbat, E.; Ariunsaikhan, T.; Odonchimeg, M.; Uurzaikh, T.; Gan-Erdene, T.; Regdel, D. Utilization of spent brewer's yeast Saccharomyces cerevisiae for the production of yeast enzymatic hydrolysate. Mong. J. Chem. 2014, 12, 88-91. [CrossRef]

25. Jacob, F.F.; Hutzler, M.; Methner, F.-J. Comparison of various industrially applicable disruption methods to produce yeast extract using spent yeast from top-fermenting beer production: Influence on amino acid and protein content. Eur. Food Res. Technol. 2019, 245, 95-109. [CrossRef]

26. Amorim, M.; Pereira, J.O.; Gomes, D.; Pereira, C.D.; Pinheiro, H.; Pintado, M.M.E. Nutritional ingredients from spent brewer's yeast obtained by hydrolysis and selective membrane filtration integrated in a pilot process. J. Food Eng. 2016, 185, 42-47. [CrossRef]

27. Dwivedi, B.; Gibson, D. Processing of Spent Brewers' Yeast for Food Use. Can. Inst. Food Technol. J. 1970, 3, 110-112. [CrossRef]

28. Shotipruk, A.; Kittianong, P.; Suphantharika, M.; Muangnapoh, C. Application of rotary microfiltration in debittering process of spent brewer's yeast. Bioresour. Technol. 2005, 96, 1851-1859. [CrossRef]

29. Nand, K. Debittering of spent brewer's yeast for food purposes. Food/Nahrung 1987, 31, 127-131. [CrossRef]

30. FAO/WHO. Report of a joint FAO/WHO/UNU Expert Consultation technical report FAO/WHO and United Nations University. In Energy and Protein Requirements; World Health Organization: Geneva, Switzerland, 1985.

31. Jacob, F.F.; Striegel, L.; Rychlik, M.; Hutzler, M.; Methner, F.-J. Yeast extract production using spent yeast from beer manufacture: Influence of industrially applicable disruption methods on selected substance groups with biotechnological relevance. Eur. Food Res. Technol. 2019, 245, 1169-1182. [CrossRef] 
32. Fsai Commission Directive. 2008/100/ECof 28 October 2008 amending Council Directive 90/496/EEC on nutrition labelling for foodstuffs as regards recommended daily allowances, energy conversion factors and definitions. Off. J. Eur. Union 2008, 51, 1-4.

33. Waters, D.M.; Kingston, W.; Jacob, F.; Titze, J.; Arendt, E.K.; Zannini, E. Wheat bread biofortification with rootlets, a malting by-product. J. Sci. Food Agric. 2013, 93, 2372-2383. [CrossRef]

34. Martini, A.E.V.; Miller, M.W.; Martini, A. Amino acid composition of whole cells of different yeasts. J. Agric. Food Chem. 1979, 27, 982-984. [CrossRef]

35. Lipke, P.N.; Ovalle, R. Cell Wall Architecture in Yeast: New Structure and New Challenges. J. Bacteriol. 1998, 180, 3735-3740. [CrossRef] [PubMed]

36. Manners, D.J.; Masson, A.J.; Patterson, J.C. The structure of a $\beta$-(1 to 3)-d-glucan from yeast cell walls. Biochem. J. 1973, 135, 19-30. [CrossRef] [PubMed]

37. Jayachandran, M.; Chen, J.; Chung, S.S.M.; Xu, B. A critical review on the impacts of $\beta$-glucans on gut microbiota and human health. J. Nutr. Biochem. 2018, 61, 101-110. [CrossRef] [PubMed]

38. Worrasinchai, S.; Suphantharika, M.; Pinjai, S.; Jamnong, P. $\beta$-Glucan prepared from spent brewer's yeast as a fat replacer in mayonnaise. Food Hydrocoll. 2006, 20, 68-78. [CrossRef]

39. Thammakiti, S.; Suphantharika, M.; Phaesuwan, T.; Verduyn, C. Preparation of spent brewer's yeast beta-glucans for potential applications in the food industry. Int. J. Food Sci. Technol. 2003, 39, 21-29. [CrossRef]

40. Arvindekar, A.U.; Patil, N.B. Glycogen-A covalently linked component of the cell wall in Saccharomyces cerevisiae. Yeast 2002, 19, 131-139. [CrossRef]

41. Cameron, D.R.; Cooper, D.G.; Neufeld, R.J. The mannoprotein of Saccharomyces cerevisiae is an effective bioemulsifier. Appl. Environ. Microbiol. 1988, 54, 1420-1425. [CrossRef]

42. Pinto, L.; Lopes, M.; Carvalho Filho, C.; Alves, L.; Benevides, C. Determinação do valor nutritivo de derivados de levedura de cervejaria (Saccharomyces spp.). Rev. Bras. Prod. Agroind. 2013, 15, 7-17. [CrossRef]

43. León-González, M.E.; Gómez-Mejía, E.; Rosales-Conrado, N.; Madrid-Albarrán, Y. Residual brewing yeast as a source of polyphenols: Extraction, identification and quantification by chromatographic and chemometric tools. Food Chem. 2018, 267, 246-254. [CrossRef]

44. Alanazi, A.M.; Mostafa, G.A.E.; Al-Badr, A.A. Profiles of Drug Substances, Excipients and Related Methodology; Elsevier: Amsterdam, The Netherlands, 2015; Volume 40, pp. 43-158.

45. Shimizu, H.; Araki, K.; Shioya, S.; Suga, K.-I. Optimal production of glutathione by controlling the specific growth rate of yeast in fed-batch culture. Biotechnol. Bioeng. 1991, 38, 196-205. [CrossRef]

46. Liu, C.-H.; Hwang, C.-F.; Liao, C.-C. Medium optimization for glutathione production by Saccharomyces cerevisiae. Process. Biochem. 1999, 34, 17-23. [CrossRef]

47. Wohlt, J.; Corcione, T.; Zajac, P. Effect of Yeast on Feed Intake and Performance of Cows Fed Diets Based on Corn Silage during Early Lactation. J. Dairy Sci. 1998, 81, 1345-1352. [CrossRef]

48. Vohra, A.; Syal, P.; Madan, A. Probiotic yeasts in livestock sector. Anim. Feed Sci. Technol. 2016, $219,31-47$. [CrossRef]

49. Harlow, B.; Bryant, R.; Cohen, S.; O'Connell, S.; Flythe, M.D. Degradation of spent craft brewer's yeast by caprine rumen hyper ammonia-producing bacteria. Lett. Appl. Microbiol. 2016, 63, 307-312. [CrossRef] [PubMed]

50. Oliveira, R.L.; Oliveira, R.J.F.; Bezerra, L.; Nascimento, T.; de Pellegrini, C.B.; de Freitas Neto, M.D.; do Nascimento, N.G., Jr.; de Souza, W.F. Substitution of corn meal with dry brewer's yeast in the diet of sheep. Rev. Colomb. Cienc. Pecu. 2016, 29, 99-107. [CrossRef]

51. Line, J.E.; Bailey, J.S.; Cox, N.A.; Stern, N.J.; Tompkins, T. Effect of yeast-supplemented feed on Salmonella and Campylobacter populations in broilers. Poult. Sci. 1998, 77, 405-410. [CrossRef] [PubMed]

52. Milewski, S.; Wójcik, R.; Zaleska, B.; Małaczewska, J.; Tański, Z.; Siwicki, A.K. Effect of Saccharomyces cerevisiae dried yeast on the meat performance traits and selected indicators of humoral immunity in lambs. Acta Vet. Brno 2013, 82, 147-151. [CrossRef]

53. Martin, D.S.; Orive, M.; Iñarra, B.; Castelo, J.; Estévez, A.; Nazzaro, J.; Iloro, I.; Elortza, F.; Zufía, J. Brewers' Spent Yeast and Grain Protein Hydrolysates as Second-Generation Feedstuff for Aquaculture Feed. Waste Biomass Valoriz. 2020, 11, 5307-5320. [CrossRef] 
54. Nguyen, N.H.Y.; Trinh, L.T.; Chau, D.T.; Baruah, K.; Lundh, T.; Kiessling, A. Spent brewer's yeast as a replacement for fishmeal in diets for giant freshwater prawn (Macrobrachium rosenbergii), reared in either clear water or a biofloc environment. Aquac. Nutr. 2019, 25, 970-979. [CrossRef]

55. Castro, C.; Pérez-Jiménez, A.; Coutinho, F.; Pousão-Ferreira, P.; Brandão, T.M.; Oliva-Teles, A.; Peres, H. Digestive enzymes of meagre (Argyrosomus regius) and white seabream (Diplodus sargus). Effects of dietary brewer's spent yeast supplementation. Aquaculture 2013, 416-417, 322-327. [CrossRef]

56. Vieira, E.F.; Ferreira, I.M. Antioxidant and antihypertensive hydrolysates obtained from by-products of cannery sardine and brewing industries. Int. J. Food Prop. 2016, 20, 662-673. [CrossRef]

57. Vieira, E.F.; Pinho, O.; Ferreira, I.M. Bio-functional properties of sardine protein hydrolysates obtained by brewer's spent yeast and commercial proteases. J. Sci. Food Agric. 2017, 97, 5414-5422. [CrossRef] [PubMed]

58. Vieira, E.F.; Van Camp, J.; Ferreira, I.; Grootaert, C. Protein hydrolysate from canned sardine and brewing by-products improves TNF- $\alpha$-induced inflammation in an intestinal-endothelial co-culture cell model. Eur. J. Nutr. 2017, 57, 2275-2286. [CrossRef] [PubMed]

59. Vieira, E.F.; Da Silva, D.D.; Carmo, H.; Ferreira, I. Protective ability against oxidative stress of brewers' spent grain protein hydrolysates. Food Chem. 2017, 228, 602-609. [CrossRef]

60. Mathias, T.R.D.S.; De Aguiar, P.F.; Silva, J.B.D.A.E.; De Mello, P.P.M.; Sérvulo, E.F.C. Brewery Waste Reuse for Protease Production by Lactic Acid Fermentation. Food Technol. Biotechnol. 2017, 55, 218-224. [CrossRef]

61. Djokoto, D.; Dzogbefia, V.; Oldham, J. Rapid Extraction of Pawpaw Juice with the Application of Locally Produced Pectic Enzymes from Saccharomyces Cerevisiae ATCC 51712. Food Biotechnol. 2006, 20, 31-41. [CrossRef]

62. Dzogbefia, V.P.; Amoke, E.; Oldham, J.H.; Ellis, W.O. Production and Use of Yeast Pectolytic Enzymes to Aid Pineapple Juice Extraction. Food Biotechnol. 2001, 15, 25-34. [CrossRef]

63. Martins, Z.E.; Pinho, O.; Ferreira, I. Impact of new ingredients obtained from brewer's spent yeast on bread characteristics. J. Food Sci. Technol. 2018, 55, 1-6. [CrossRef]

64. Pancrazio, G.; Cunha, S.C.; De Pinho, P.G.; Loureiro, M.; Meireles, S.; Ferreira, I.; Pinho, O. Spent brewer's yeast extract as an ingredient in cooked hams. Meat Sci. 2016, 121, 382-389. [CrossRef]

65. Wieser, H. Chemistry of gluten proteins. Food Microbiol. 2007, 24, 115-119. [CrossRef]

66. Yano, H. Comparison of Oxidized and Reduced Glutathione in the Bread-Making Qualities of Rice Batter. J. Food Sci. 2012, 77, C182-C188. [CrossRef] [PubMed]

67. Verheyen, C.; Albrecht, A.; Herrmann, J.; Strobl, M.; Jekle, M.; Becker, T. The contribution of glutathione to the destabilizing effect of yeast on wheat dough. Food Chem. 2015, 173, 243-249. [CrossRef] [PubMed]

68. Henrion, M.; Francey, C.; Lê, K.-A.; Lamothe, L. Cereal B-Glucans: The Impact of Processing and How It Affects Physiological Responses. Nutrients 2019, 11, 1729. [CrossRef] [PubMed]

69. Mantovani, M.S.; Bellini, M.F.; Angeli, J.P.F.; Oliveira, R.J.; Silva, A.F.; Ribeiro, L.R. $\beta$-Glucans in promoting health: Prevention against mutation and cancer. Mutat. Res. Rev. Mutat. Res. 2008, 658, 154-161. [CrossRef]

70. Waszkiewicz-Robak, B.; Bartnikowska, E. Effects of spent brewer's yeast and biological $\beta$-glucans on selected parameters of lipid metabolism in blood and liver in rats. J. Anim. Feed Sci. 2009, 18, 699-708. [CrossRef]

71. Bell, S.; Goldman, V.M.; Bistrian, B.R.; Arnold, A.H.; Ostroff, G.; Forse, R.A. Effect of $\beta$-Glucan from Oats and Yeast on Serum Lipids. Crit. Rev. Food Sci. Nutr. 1999, 39, 189-202. [CrossRef]

72. Zhu, F.; Du, B.; Xu, B. A critical review on production and industrial applications of beta-glucans. Food Hydrocoll. 2016, 52, 275-288. [CrossRef]

73. Salgado, M.; Santos, F.; Rodríguez-Rojo, S.; Reis, R.L.; Duarte, A.R.C.; Cocero, M.J. Development of barley and yeast $\beta$-glucan aerogels for drug delivery by supercritical fluids. J. CO2 Util. 2017, 22, 262-269. [CrossRef]

74. Marson, G.V.; Saturno, R.P.; Comunian, T.A.; Consoli, L.; Machado, M.T.D.C.; Hubinger, M.D. Maillard conjugates from spent brewer's yeast by-product as an innovative encapsulating material. Food Res. Int. 2020, 136, 109365. [CrossRef]

75. Guedes, J.D.S.; Pimentel, T.C.; Diniz-Silva, H.T.; Almeida, E.T.D.C.; Tavares, J.F.; De Souza, E.L.; Garcia, E.F.; Magnani, M. Protective effects of $\beta$-glucan extracted from spent brewer yeast during freeze-drying, storage and exposure to simulated gastrointestinal conditions of probiotic lactobacilli. LWT 2019, 116, 108496. [CrossRef]

76. Vieira, E.F.; Das Neves, J.; Vitorino, R.; Dias-Da-Silva, D.; Carmo, H.; Ferreira, I. Impact of in Vitro Gastrointestinal Digestion and Transepithelial Transport on Antioxidant and ACE-Inhibitory Activities of Brewer's Spent Yeast Autolysate. J. Agric. Food Chem. 2016, 64, 7335-7341. [CrossRef] [PubMed] 
77. Vieira, E.F.; Melo, A.; Ferreira, I.M. Autolysis of intracellular content of Brewer's spent yeast to maximize ACE-inhibitory and antioxidant activities. LWT 2017, 82, 255-259. [CrossRef]

78. Marson, G.V.; Machado, M.T.D.C.; De Castro, R.J.S.; Hubinger, M.D. Sequential hydrolysis of spent brewer's yeast improved its physico-chemical characteristics and antioxidant properties: A strategy to transform waste into added-value biomolecules. Process. Biochem. 2019, 84, 91-102. [CrossRef]

79. Komorowska, A.; Sieliwanowicz, B.; Mrówka, E.; Stecka, K.; Ha, A. Studies on yeast extracts enriched in $5^{\prime}$ nucleotides flavour enhancers obtained from spent brewery yeast. Electron. J. Polish Agric. Univ. 2003, 6, 3.

80. Vieira, E.; Brandão, T.; Ferreira, I. Evaluation of Brewer's Spent Yeast to Produce Flavor Enhancer Nucleotides: Influence of Serial Repitching. J. Agric. Food Chem. 2013, 61, 8724-8729. [CrossRef]

81. Rakowska, R.; Sadowska, A.; Dybkowska, E.; Świderski, F. Spent yeast as natural source of functional food additives. Rocz. Państwowego Zakładu Hig. 2017, 68, 115-121.

82. Varavinit, S.; Shobsngob, S.; Bhidyachakorawat, M.; Suphantharika, M. Production of Meat-Like Flavor. Sci. Asia 2000, 26, 219-224. [CrossRef]

83. Alim, A.; Yang, C.; Song, H.; Liu, Y.; Zou, T.; Zhang, Y.; Zhang, S. The behavior of umami components in thermally treated yeast extract. Food Res. Int. 2019, 120, 534-543. [CrossRef]

84. Cameron, J.S.; Moro, F.; Simmonds, H.A. Gout, uric acid and purine metabolism in paediatric nephrology. Pediatr. Nephrol. 1993, 7, 105-118. [CrossRef]

85. Trevelyan, W.E. Chemical methods for the reduction of the purine content of baker's yeast, a form of single-cell protein. J. Sci. Food Agric. 1976, 27, 225-230. [CrossRef]

86. Canepa, A.; Pieber, M.; Romero, C.; Tohá, J.C. A method for large reduction of the nucleic acid content of yeast. Biotechnol. Bioeng. 1972, 14, 173-177. [CrossRef]

87. Wiebe, M.G. Myco-protein from Fusarium venenatum: A well-established product for human consumption. Appl. Microbiol. Biotechnol. 2002, 58, 421-427. [CrossRef] [PubMed]

88. Trevelyan, W.E. Autolytic methods for the reduction of the purine content of baker's yeast, a form of single-cell protein. J. Sci. Food Agric. 1976, 27, 753-762. [CrossRef] [PubMed]

89. Gibson, D.; Dwivedi, B. Production of Meat Substitutes from Spent Brewers' Yeast and Soy Protein. Can. Inst. Food Technol. J. 1970, 3, 113-115. [CrossRef]

90. Dwivedi, B.; Gibson, D.; Bell, J. Nutritive Value of Meat Substitute Prepared from Brewers' Yeast and Isolated Soy Protein. Can. Inst. Food Sci. Technol. J. 1972, 5, 155-158. [CrossRef]

91. Mathias, T.R.D.S.; Alexandre, V.M.F.; Cammarota, M.C.; De Mello, P.P.M.; Sérvulo, E.F.C. Characterization and determination of brewer's solid wastes composition. J. Inst. Brew. 2015, 121, 400-404. [CrossRef]

92. Radosavljević, M.; Pejin, J.; Pribić, M.; Kocić-Tanackov, S.; Mladenović, D.; Djukić-Vuković, A.; Mojović, L. Brewing and malting technology by-products as raw materials in L-(+)-lactic acid fermentation. J. Chem. Technol. Biotechnol. 2020, 95, 339-347. [CrossRef]

93. Sawisit, A.; Seesan, S.; Chan, S.; Kanchanatawee, S.; Jantama, S.S.; Jantama, K. Validation of Fermentative Parameters for Efficient Succinate Production in Batch Operation by Actinobacillus succinogenes 130ZT. Adv. Mater. Res. 2012, 550, 1448-1454. [CrossRef]

94. Neira, K.; Jeison, D. Anaerobic co-digestion of surplus yeast and wastewater to increase energy recovery in breweries. Water Sci. Technol. 2010, 61, 1129-1135. [CrossRef]

95. Sosa-Hernández, O.; Parameswaran, P.; Alemán-Nava, G.S.; Torres, C.I.; Parra-Saldívar, R. Evaluating biochemical methane production from brewer's spent yeast. J. Ind. Microbiol. Biotechnol. 2016, 43, 1195-1204. [CrossRef]

96. Bocher, B.T.; Agler, M.; Garcia, M.L.; Beers, A.R.; Angenent, L.T. Anaerobic digestion of secondary residuals from an anaerobic bioreactor at a brewery to enhance bioenergy generation. J. Ind. Microbiol. Biotechnol. 2008, 35, 321-329. [CrossRef] [PubMed]

97. Zupančič, G.D.; Škrjanec, I.; Logar, R.M. Anaerobic co-digestion of excess brewery yeast in a granular biomass reactor to enhance the production of biomethane. Bioresour. Technol. 2012, 124, 328-337. [CrossRef] [PubMed]

98. Šafaříková, M.; Ptáčková, L.; Kibriková, I.; Šafařík, I. Biosorption of water-soluble dyes on magnetically modified Saccharomyces cerevisiae subsp. uvarum cells. Chemosphere 2005, 59, 831-835. [CrossRef] [PubMed]

99. Ferraz, A.; Tavares, T.; Teixeira, J.A. Cr (III) removal and recovery from. Chem. Eng. J. 2004, 105, 11-20. [CrossRef]

100. Riordan, C.; Bustard, M.; Putt, R.; McHale, A.P. Removal of uranium from solution using residual brewery yeast: Combined biosorption and precipitation. Biotechnol. Lett. 1997, 19, 385-388. [CrossRef] 
101. Machado, M.D.; Santos, M.S.F.; Gouveia, C.; Soares, H.M.V.M.; Soares, E.V. Removal of heavy metals using a brewer's yeast strain of Saccharomyces cerevisiae: The flocculation as a separation process. Bioresour. Technol. 2008, 99, 2107-2115. [CrossRef]

102. Laopaiboon, L.; Sridee, W.; Jaisil, P.; Laopaiboon, P. The use of dried spent yeast as a low-cost nitrogen supplement in ethanol fermentation from sweet sorghum juice under very high gravity conditions. Electron. J. Biotechnol. 2011, 14. [CrossRef]

103. Kawa-Rygielska, J.; Pietrzak, W. Ethanol fermentation of very high gravity (VHG) maize mashes by Saccharomyces cerevisiae with spent brewer's yeast supplementation. Biomass Bioenergy 2014, 60, 50-57. [CrossRef]

Publisher's Note: MDPI stays neutral with regard to jurisdictional claims in published maps and institutional affiliations.

(C) 2020 by the authors. Licensee MDPI, Basel, Switzerland. This article is an open access article distributed under the terms and conditions of the Creative Commons Attribution (CC BY) license (http://creativecommons.org/licenses/by/4.0/). 